\title{
Counterproductive Effects of Rice For Poor (Raskin) Program on Labor Supply
}

\author{
Eka Riski Ningtiyas ${ }^{1}$ \\ Ministry of National Development Planning/Bappenas \\ Indonesia
}

\begin{abstract}
This study aims to examine the existence of counterproductive effects of Rice For Poor (Raskin) program on labor supply. The impact evaluation is done by a combination of Difference-in-Difference and Propensity Score Matching methods. The estimation results shown that Raskin has a significant impact on decreasing of households head working hours, especially on male. Based on these findings, it can be concluded that Raskin has a counterproductive effect on labor supply, but there is no evidence to say Raskin makes people lazy.
\end{abstract}

Keywords: counterproductive effect, labor supply, rice for poor

\footnotetext{
${ }^{1}$ Eka Riski Ningtiyas is a staff at Directorate of Allocation of Development Funding, Ministry of National Development Planning/Bappenas. Email: eka.ningtyas@bappenas.go.id
} 


\title{
Efek Kontraproduktif Program Raskin pada Penawaran \\ Tenaga Kerja
}

\author{
Eka Riski Ningtiyas, Bappenas
}

\section{Pendahuluan}

Pemberian bantuan pangan merupakan kebijakan yang umum dilakukan untuk mengatasi kerawanan pangan di beberapa negara. Bantuan pangan baik berupa pemberian makanan langsung, food for work, food for training ataupun subsidi pangan pada dasarnya bertujuan untuk meringankan beban rumah tangga dan memperkuat ketahanan pangan keluarga. Di Indonesia, bantuan pangan kepada rumah tangga miskin diberikan dalam bentuk pemberian subsidi harga beras yang dikenal dengan program Raskin. Dengan adanya program Raskin diharapkan dapat membantu kelompok miskin dan rentan miskin mendapat cukup pangan dan nutrisi karbohidrat tanpa kendala.

Namun pemberian bantuan pangan ini masih menjadi perdebatan karena menimbulkan beberapa dampak sampingan yang tidak diharapkan, salah satunya adalah pengurangan terhadap penawaran tenaga kerja (Barret, 2006). Menurut Barret (2006) bantuan pangan memang tidak didesain untuk menimbulkan efek disinsentif atau membuat orang malas bekerja. Namun dengan menggunakan teori ekonomi penawaran tenaga kerja statis dapat dijelaskan bahwa pemberian bantuan pangan dapat menyebabkan pengurangan waktu bekerja (Skoufias, Unar dan Gonzalez-Cosio, 2008). Bantuan pangan dapat dilihat sebagai tambahan pendapatan di luar bekerja (non-earned income) yang akan menggeser garis anggaran dan mempengaruhi keputusan bekerja individu. Penambahan pendapatan ini menimbulkan efek pendapatan (income effect), dan menyebabkan individu mengkonsumsi lebih banyak leisure yang mengurangi alokasi waktu bekerja individu tersebut. Dalam konteks ini pemberian bantuan pangan potensial memiliki efek kontraproduktif pada penawaran kerja individu penerima bantuan.

Adanya efek kontraproduktif program Raskin ini juga telah disampaikan oleh Studi mengenai dampak bantuan pangan terhadap penawaran tenaga kerja di Indonesia belum banyak dilakukan. Rasyid (2012). Dalam penelitiannya, Rasyid (2012) menyampaikan bahwa pemberian program Raskin pada rumah tangga miskin dapat mengurangi probabilitas kepala keluarga untuk bekerja sehingga pendapatan keluarga dari bekerja menurun signifikan. Namun terdapat hal yang perlu dikritisi dari penelitian Rasyid (2012), yaitu dari sisi metodologi yang digunakan. 
Penggunaan metode First Difference menghasilkan analisis dampak yang kurang akurat karena dapat menimbulkan bias. Estimasi dampak dengan membandingkan probabilitas status bekerja kepala keluarga penerima Raskin pada periode sebelum dan sesudah pelaksanaan Raskin akan menimbulkan bias terutama disebabkan oleh perkembangan waktu (Khandker, Koolwal dan Samad, 2009). Dengan jarak waktu observasi yang cukup lama yaitu tujuh tahun, bisa jadi penurunan probabilitas bekerja kepala rumah tangga juga disebabkan oleh penambahan usia dimana kepala rumah tangga dihadapkan pada masa pensiun atau kondisi yang lain. Jika hal ini tidak dikontrol maka estimasi yang dihasilkan menjadi overestimates dan berpotensi bias.

Berdasarkan hal tersebut di atas penelitian ini bertujuan untuk memeriksa kembali adanya efek kontraproduktif pemberian program Raskin pada penawaran tenaga kerja. Untuk mengatasi bias yang disebabkan perkembangan waktu seperti pada penelitian Rasyid (2012), penelitian ini menggunakan metode Difference-inDifference (DID) yaitu dengan membandingkan outcome pada kelompok perlakuan dan kontrol pada periode sebelum dan sesudah pelaksanaan Raskin.

Kelompok perlakuan dibentuk dari kelompok rumah tangga miskin yang tercatat sebagai penerima program Raskin. Sedangkan kelompok kontrol dibentuk dari kelompok rumah tangga miskin yang seharusnya menerima Raskin, namun bukan tercatat sebagai penerima Raskin (exclusion error). Untuk menjamin terpenuhinya asumsi paralel-trend pada DID maka penelitian ini juga menggunakan metode Propensity Score Matching (PSM) untuk membentuk kelompok kontrol yang memiliki karakteristik hampir sama dengan kelompok perlakuan.

\section{Tinjauan Literatur}

\subsection{Model Penawaran Tenaga Kerja Statis}

Dalam model penawaran tenaga kerja statis, pemberian subsidi Raskin menyebabkan pengurangan penawaran tenaga kerja dalam rumah tangga. Subsidi Raskin diasumsikan sebagai in-kind transfer yang dapat meningkatkan pendapatan potensial rumah tangga. Adanya efek pendapatan ini menyebabkan rumah tangga lebih sejahtera dan akan mengkonsumsi lebih banyak barang dan leisure dan menyebabkan rumah tangga mengurangi jam kerjanya.

Rumah tangga diasumsikan memaksimalkan fungsi utility $U\left(C_{F}, C_{N F}, L\right)$. Dalam memaksimalkan utility-nya tersebut rumah tangga menghadapi kendala angga$\operatorname{ran} P_{F} C_{F}+P_{N F} C_{N F}+W L=R+W L$, dimana $C_{F}, C_{N F}$ dan $L$ masing-masing menunjukkan konsumsi makanan, konsumsi bukan makanan dan leisure, sedangkan $P_{F}, P_{N F}$, dan $W$ masing-masing adalah harga untuk makanan, bukan makanan dan waktu, $\mathrm{R}$ 
adalah pendapatan di luar bekerja, dan $L_{0}$ adalah total waktu yang dimiliki rumah tangga (24 jam). Permasalahan tersebut ditunjukkan oleh persamaan di bawah ini

$$
\max _{(C F, C N F, L)} U\left(C_{F}, C_{N F}, L\right) \text { s.t } P_{F} C_{F}+P_{N F} C_{N F}+W L=R+W L_{0}
$$

Dengan menggunakan $\lambda \geq 0$ sebagai Lagrange multiplier, persamaan Lagrangian dapat ditulis sebagai

$$
L\left(C_{F}, C_{N F}, L, \lambda\right)=U\left(C_{F} C_{N F}, L\right)+\lambda\left(R+W L_{0}-P_{F} C_{F}-P_{N F} C_{N F}-W L\right)
$$

Dari permasalahan tersebut di atas dapat diketahui bahwa pilihan rumah tangga atas konsumsi makanan, bukan makanan dan leisure yang optimal akan memenuhi persamaan berikut

$$
U_{F} / U_{N F}=P_{F} / P_{N F} ; U_{F} / U_{L}=P_{F} / W ; U_{N F} / U_{L}=P_{N F} / W
$$

Ketika rumah tangga tersebut menerima subsidi Raskin berupa bantuan pangan dalam kuantitas tertentu yang nilainya sama dengan uang tunai sebesar $T$, terjadi peningkatan pendapatan potensial. Hal ini akan menyebabkan garis kendala anggaran akan bergeser ke kanan sebesar $T / P_{F}$, namun daerah yang berada di sudut kiri atas tidak terpenuhi karena subsidi Raskin tersebut hanya berpengaruh pada konsumsi makanan saja (gambar 1). Dari gambar 1 tersebut dapat dilihat bahwa pemberian subsidi Raskin akan menyebabkan penambahan konsumsi makanan dan bukan makanan (geser dari A ke $A^{\star}$ ). Dengan menggunakan kondisi optimal pada persamaan (3) dan dengan asumsi leisure adalah barang normal, pemberian bantuan pangan akan menyebabkan penambahan leisure yang artinya terjadi pengurangan waktu bekerja rumah tangga.

Gambar 1. Dampak pemberian bantuan pangan pada model penawaran kerja statis

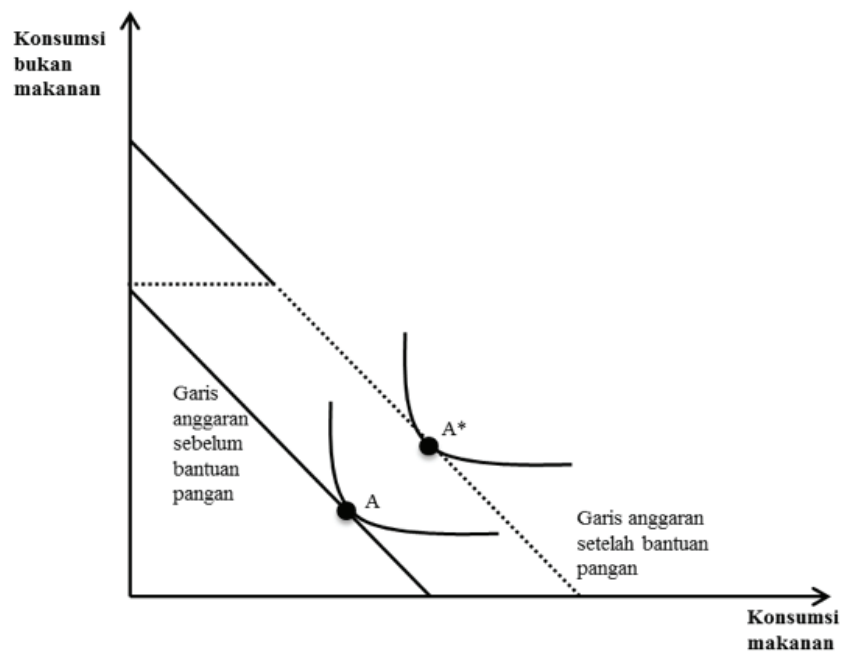




\subsection{Studi Empiris.}

Walaupun dalam model penawaran tenaga kerja statis di atas secara jelas ditunjukkan bahwa pemberian bantuan pangan akan mengurangi penawaran tenaga kerja, namun sampai saat ini hasil empiris menunjukkan hasil yang berbeda. Jackson (1982), Sahn dan Alderman (1996) menemukan bahwa pemberian bantuan pangan dapat mengurangi penawaran tenaga kerja penerima. Hal yang hampir sama juga didapatkan dari penelitian Sulaiman (2010). Walaupun tidak cukup bukti bahwa subsidi pangan dapat menurunkan semangat kerja, terdapat dampak negatif pemberian subsidi pangan pada pendapatan rumah tangga. Hal ini diduga dikarenakan adanya penurunan jam kerja anak, mengingat adanya hubungan positif antara pemberian bantuan dengan tingkat partisipasi sekolah anak.

Sementara Stevens (1979), Maxwell et al. (1994), Abdulai, Barret dan Hoddinot (2005) dan Skoufias, Unar dan Gonzalez-Cosio (2008) menunjukkan hasil sebaliknya bahwa tidak ditemukan cukup bukti adanya efek disinsentif subsidi pangan terhadap penawaran tenaga kerja. Menurut Skoufias, Unar dan Gonzalez-Cosio (2008), pemberian bantuan pangan diduga tidak memberikan dampak signifikan terhadap penawaran tenaga kerja dikarenakan efek pendapatan yang ditimbulkan relatif kecil. Besarnya bantuan yang diterima tidak sepadan dengan beban pengeluaran yang ditanggung sehingga mengharuskan penerima bantuan untuk tetap bekerja.

Lebih jauh, Barret (2006) menyatakan bahwa dampak negatif bantuan pangan terhadap penawaran tenaga kerja utamanya diakibatkan adanya kesalahan dalam penentuan sasaran penerima bantuan (targeting error). Penawaran tenaga kerja akan semakin responsif terhadap perubahan pendapatan ketika seseorang sudah lebih sejahtera. Hal ini mengindikasikan bahwa efek disinsentif terhadap penawaran tenaga kerja terjadi pada kelompok yang masuk kategori inclusion error. Dengan demikian, jika subsidi pangan sudah didesain dengan baik maka tidak perlu lagi khawatir adanya disinsentif terhadap penawaran tenaga kerja.

Kesalahan penetapan sasaran juga menjadi permasalahan utama yang dihadapi dalam pelaksanaan Program Raskin (Hastuti et al, 2008). Kesalahan penetapan sasaran ini bisa dilihat dari masih adanya rumah tangga yang berhak menerima bantuan namun tidak mendapat manfaat dari program tersebut (exclusion error), serta ada rumah tangga yang tidak berhak menerima bantuan namun menjadi penerima Raskin (inclusion error). Kesalahan penargetan sasaran penerima Raskin ini dapat dianalisis dengan berbagai cara. Hastuti et al (2008) menunjukkan adanya kesalahan dalam penetapan sasaran penerima Raskin melalui pengeluaran per kapita rumah tangga. Beras Raskin seharusnya hanya diterima oleh rumah tangga 
yang pengeluaran per kapitanya berada di kuintil 1 dan 2. Namun menurut hasil Susenas, beras Raskin diterima oleh semua kelompok rumah tangga berdasarkan kuintil pengeluaran per kapita. Persentase rumah tangga dari kuintil 1 dan 2 yang merupakan kelompok paling tidak sejahtera hanya mencapai 53 persen dari total penerima Raskin. Selebihnya 47 persen merupakan rumah tangga tergolong mampu di kuintil 3-5, yang seharusnya sama sekali tidak mendapat beras Raskin.

Ketepatan target dapat diketahui juga dengan melihat proporsi rumah tangga miskin dan tidak miskin yang terjangkau dan tidak terjangkau Raskin (Hastuti et al, 2008). Hasil pengolahan data Susenas menunjukkan bahwa selama 2005 2006, proporsi rumah tangga miskin yang terjangkau Program Raskin meningkat dari 62,9 persen menjadi 82,7 persen. Namun peningkatan jangkauan terhadap rumah tangga miskin tersebut juga dibarengi dengan peningkatan jangkauan terhadap rumah tangga tidak miskin yaitu dari 23,8 persen menjadi 31,8 persen.

Adanya kesalahan dalam penentuan sasaran penerimajuga bisa dilihat dengan memperhatikan kriteria rumah tangga sasaran penerima program. Noroyono (2011) menunjukkan cara yang serupa ketika menunjukkan exclusion error pada pelaksanaan Bantuan Langsung Tunai (BLT) tahun 2008-2009. Dengan menggunakan tujuh kriteria dari 14 kriteria rumah tangga penerima BLT, ditemukan sekitar 43,9 persen dan 54,2 persen exclusion error pada pelaksanaan BLT tahun 2008 dan 2009. Namun hal ini tidak dapat dilaksanakan pada program Raskin. Hal ini dikarenakan sesuai dengan Pedoman Umum Raskin tahun 2013, kriteria rumah tangga yang berhak mendapat Raskin adalah rumah tangga sasaran yang terdaftar dalam Basis Data Terpadu (BDT) untuk Progam Perlindungan Sosial yang bersumber dari PPLS 2011 BPS dan dikelola oleh Tim Nasional Percepatan Penanggulangan Kemiskinan (TNP2K). Kriteria rumah tangga sasaran Raskin seperti yang disebut di atas lebih bersifat prosedural sehingga tidak jelas kriteria rumah tangga yang berhak menerima Raskin (Sitepu, 2014).

\section{Metodologi}

Program Raskin yang dimulai sejak tahun 2002 telah menjangkau ke seluruh wilayah Indonesia. Data TNP2K menyebutkan bahwa distribusi Raskin telah dilakukan pada 1.114 kelurahan/desa di seluruh propinsi di Indonesia. Berdasarkan hal tersebut di atas, dirasa tidak memungkinkan untuk melakukan estimasi dampak dengan metode pengacakan. Oleh karena itu, penelitian ini menggunakan desain quasi eksperimental.

Dalam desain ini, kelompok perlakuan dan kelompok pembanding dibentuk setelah pelaksanaan program dengan menggunakan metode tidak acak, dimana 
kelompok perlakuan dibentuk dari rumah tangga miskin yang menerima Raskin. Sedangkan kelompok kontrol dibentuk dari rumah tangga miskin yang seharusnya berhak menerima Raskin namun tidak tercatat sebagai penerima Raskin. Selanjutnya estimasi dampak dilakukan dengan menggunakan metode Difference-in-Difference (DID).

Pada dasarnya cara kerja DID adalah membandingkan perubahan outcome pada kelompok perlakuan dan kelompok kontrol pada periode sebelum dan sesudah pelaksanaan program Raskin (Khandker, Koolwal dan Samad, 2009). Metode ini merupakan metode yang lazim digunakan dalam melakukan evaluasi dampak kebijakan karena dapat mengatasi potensi bias karena perubahan faktor lain akibat perkembangan waktu. Namun perlu diingat bahwa untuk mendapatkan hasil estimasi DID yang baik, terdapat asumsi penting yang harus dipenuhi yaitu asumsi paralell-trend (Khandker, Koolwal dan Samad, 2009). Asumsi ini menyebutkan bahwa gangguan acak (error term) tidak berkorelasi dengan variabel lain dalam persamaan. Asumsi ini ini mengindikasikan bahwa faktor-faktor lain yang tidak diamati yang dapat mempengaruhi program tidak berubah antar waktu baik pada kelompok perlakuan dan kelompok kontrol. Artinya tanpa adanya perlakuan/ pemberian program, outcome pada kelompok perlakuan akan bergerak paralel dengan outcome pada kelompok. Pada prakteknya asumsi ini sulit dipenuhi, terutama jika kelompok pembanding (kontrol) dibentuk dari kelompok rumah tangga yang tidak menerima perlakuan (Gertler et al, 2011). Adanya heterogenitas individu terkait perbedaan karakteristik, baik yang dapat diamati atau tidak diamati, dapat menyebabkan asumsi paralel-trend tersebut diatas terlanggar. Untuk itu, penelitian ini juga menggunakan metode Propensity Score Matching (PSM).

Metode Propensity Score Matching (PSM) adalah metode pencocokan yang menggunakan teknik statistik untuk membentuk kelompok pembanding (kelompok kontrol) yang didasarkan pada probabilitas partisipasi peserta dalam program berdasarkan beberapa karakteristik yang bisa diobservasi. Secara sederhana dalam metode PSM ini rumah tangga miskin penerima Raskin akan dicocokkan dengan rumah tangga miskin bukan penerima Raskin dengan menggunakan basis propensity score yang menunjukkan probabilitas rumah tangga tersebut berpartisipasi dalam Raskin.

Dalam membentuk propensity score, penelitian ini menggunakan beberapa variabel yang diduga mempengaruhi partisiasi rumah tangga dalam pelaksanaan program Raskin. Bappenas (2010) menyatakan bahwa partisipasi rumah tangga miskin dalam program-program penanggulangan kemiskinan seperti Raskin 
tidak hanya dilihat berdasarkan data makro seperti pengeluaran, tetapi perlu menggunakan data yang bersifat mikro yaitu dengan menggunakan pendekatan karakteristik rumah tangga. Untuk itu variabel yang diduga mempengaruhi partisipasi rumah tangga dalam program Raskin dalam penelitian ini adalah pengeluaran konsumsi perkapita, luas lantai perkapita, jenis lantai, jenis dinding, fasilitas sanitasi, sumber penerangan, sumber air, jenis atap, status kepemilikan rumah, jumlah anggota rumah tangga, jenis kelamin anggota rumah tangga, usia kepala rumah tangga, tingkat pendidikan kepala rumah tangga, status bekerja kepala rumah tangga dan lapangan pekerjaan kepala rumah tangga. Selanjutnya dilakukan proses pencocokan dengan menentukan daerah common support dan balancing test. Daerah common support menunjukkan daerah dimana distribusi propensity score dari individu dalam kelompok perlakuan dan kelompok kontrol saling tumpang tindih (overlap). Sedangkan balancing test digunakan untuk memeriksa apakah kelompok perlakuan dan kelompok kontrol memiliki propensity score yang seimbang untuk setiap variabel yang diamati. Ketika setiap variabel yang diamati telah seimbang maka individu pada kelompok perlakuan dan kelompok kontrol yang berada dalam common support inilah yang disebut sebagai sampel yang cocok (matched sample) dan memiliki karakteristik yang setara/mirip dengan kelompok perlakuan berdasarkan faktor-faktor yang dapat diamati. Dengan demikian apabila kelompok kontrol ini digunakan dalam estimasi dampak DID akan menyebabkan asumsi paralell-trend dapat dipenuhi

Setelah didapatkan kelompok perlakuan dan kelompok kontrol yang memiliki karakteristik yang hampir sama, maka estimasi dampak dari program Raskin terhadap penawaran tenaga kerja dapat dilakukan dengan menggunakan persamaan sebagai berikut

$$
Y_{i t}=\alpha+\beta T_{i 1}+\gamma t+\delta\left(T_{i 1}^{*} t\right)+\theta X R T_{i t}+\varepsilon_{i t}
$$

dimana $Y$ merupakan variabel outcome yaitu jumlah jam kerja dari seluruh pekerjaan dalam seminggu, baik dari pekerjaan. $T$ menunjukkan variabel dummy perlakuan, dimana bernilai 1 jika rumah tangga menerima program Raskin, dan 0 jika rumah tangga tidak menerima program Raskin pada tahun 2007 $(t=1)$. $t$ merupakan variabel dummy waktu, dimana bernilai 1 jika pada akhir program (2007) dan 0 jika di awal program (2005). Sedangkan XRT menunjukkan variabel karakteristik rumah tangga yang digunakan dalam proses pencocokan. 


\subsection{Data}

Data yang digunakan dalam penelitian ini adalah data mentah (raw data) yang bersumber dari data Survei Sosial Ekonomi Nasional (Susenas) Panel tahun 2005 dan 2007 yang dipublikasikan oleh Badan Pusat Statistik (BPS). Pemilihan tahun observasi dalam penelitian ini didasarkan atas ketersediaan dan kelengkapan data yang diperlukan. Jenis data yang digunakan dalam penelitian ini adalah jenis data panel. Walaupun penggunaan metode DID dapat dilakukan dengan data panel dan data cross-section, namun menurut Lechner (2010) penggunaan data panel memiliki kelebihan dibanding cross-section. Dengan data panel, proses pencocokan karakteristik kelompok perlakuan dan kelompok kontrol dapat dilakukan berdasarkan data pada periode baseline sehingga dapat dibentuk kelompok pembanding (kontrol) yang memiliki rata-rata outcome yang sama.

\section{Hasil Dan Analisis}

Data yang diolah dalam penelitian ini merupakan data yang diperoleh dengan menggabungkan hasil pengolahan data tahun 2005 dan 2007. Gabungan dari data 2005 dan 2007 tersebut menghasilkan sebanyak 8.934 rumah tangga dan 20.101 individu yang sama. Data gabung tersebut kemudian dilakukan identifikasi terkait rumah tangga dengan status miskin dan status penerimaan Raskin tahun 2005-2007. Melalui tabulasi silang antara status penerimaan Raskin dengan rumah tangga yang teridentifikasi sebagai rumah tangga miskin maka dapat dilihat sejauh mana keberhasilan Raskin dapat tepat sasaran dirasakan oleh rumah tangga miskin.

Dari hasil tabulasi silang tahun 2005 pada tabel 1, dapat dilihat bahwa rumah tangga miskin yang mendapat Raskin hanya sebesar 652 rumah tangga dari total 1.106 rumah tangga miskin atau hanya sekitar 58,95 persen. Sedangkan sisanya 41,05 persen rumah tangga miskin tetapi tidak mendapatkan Raskin (exclusion error). Dari tabel 1 juga dapat dilihat bahwa ada 2.547 rumah tangga yang tidak berhak menerima Raskin tetapi malah mendapatkan Raskin (inclusion error) atau sekitar 32,53 persen dari total rumah tangga tidak miskin. Hal ini mengindikasikan bahwa pada tahun 2005 masih banyak terjadi kebocoran pembagian Raskin kepada yang tidak berhak. Menurut Hastuti et al (2008) kesalahan target pelaksanaan Raskin ini disebabkan oleh kurangnya ketegasan dan keseriusan kepala daerah dalam membagi Raskin hanya kepada rumah tangga miskin. Di beberapa wilayah ditemukan bahwa pembagian Raskin cenderung dengan cara bagi rata atau sistem gilir sehingga rumah tangga yang tidak miskin pun akhirnya menerima beras Raskin. 
Tabel 1. Hasil tabulasi silang rumah tangga dan penerimaan Raskin 2005

\begin{tabular}{lcccc}
\hline \multirow{2}{*}{ Tahun 2005 } & \multicolumn{2}{c}{ Miskin } & Total \\
& & $\mathbf{0}$ & $\mathbf{1}$ & \\
\hline \multirow{2}{*}{ Raskin } & $\mathbf{0}$ & 5.281 & 454 & 5.735 \\
& $\mathbf{1}$ & 2.547 & 652 & 3.199 \\
\multirow{2}{*}{ Total } & & 7.828 & 1.106 & 8.934 \\
\hline
\end{tabular}

Dengan mengasumsikan bahwa status rumah tangga miskin tidak berubah pada tahun 2007, maka hasil tabulasi silang pada tahun 2007 dapat dilihat pada tabel 2. Dari tabel tersebut dapat dilihat bahwa pada tahun 2007 masih terdapat exclusion dan inclusion error dalam pelaksanaan Raskin. Rumah tangga miskin yang mendapat Raskin hanya sebesar 748 rumah tangga dari total 1.106 rumah tangga miskin atau hanya sekitar 67,63 persen. Sedangkan sisanya 34,81 persen rumah tangga miskin tetapi tidak mendapatkan Raskin (exclusion error). Dapat dilihat juga bahwa terdapat 3.305 rumah tangga yang tidak berhak menerima Raskin tetapi malah mendapatkan Raskin (inclusion error) atau sekitar 42,22 persen dari total rumah tangga tidak miskin.

Tabel 2. Hasil tabulasi silang rumah tangga miskin penerima Raskin tahun 2007

\begin{tabular}{|c|c|c|c|c|}
\hline \multirow{2}{*}{\multicolumn{2}{|c|}{ Tahun 2007}} & \multicolumn{2}{|c|}{ Miskin } & \multirow{2}{*}{ Total } \\
\hline & & 0 & 1 & \\
\hline \multirow{2}{*}{ Raskin } & 0 & 4.523 & 385 & 4.881 \\
\hline & 1 & 3.305 & 748 & 4.053 \\
\hline \multicolumn{2}{|c|}{ Total } & 7.828 & 1.106 & 8.934 \\
\hline
\end{tabular}

Dari hasil tabulasi silang tahun 2005 dan 2007 di atas dapat disimpulkan bahwa terdapat kesalahan dalam penentuan sasaran rumah tangga penerima Raskin pada tahun 2005 dan 2007. Hal ini bisa dilihat masih besarnya tingkat exclusion dan inclusion error pada pelaksanaan Raskin. Kesalahan penetapan sasaran program Raskin juga dapat dilihat melalui proporsi rumah tangga miskin dan tidak miskin yang mendapat Raskin (Hastuti et al, 2008). Dari tabel 1 dan tabel 2 dapat dilihat bahwa selama 20052007, proporsi rumah tangga miskin yang mendapat Program Raskin meningkat dari 58,95 persen menjadi 67,63 persen. Namun sayangnya peningkatan jangkauan terhadap rumah tangga miskin tersebut juga dibarengi dengan peningkatan jangkauan terhadap rumah tangga tidak miskin yaitu dari 32,53 persen menjadi 42,22 persen.

Perubahan jangkauan tersebut di atas mengindikasikan adanya rumah tangga yang mengalami perubahan status penerimaan Raskin pada periode 2005- 
2007. Hal ini menjadi hambatan ketika akan membentuk kelompok perlakuan dan kelompok kontrol karena seyogyanya status penerimaan Raskin tidak berubah untuk mendapatkan hasil estimasi dampak yang baik. Pada kasus semacam ini, jika hanya menggunakan sampel rumah tangga yang status penerimaan Raskinnya tidak berubah maka akan memotong ukuran sampel dan terjadi yang disebut sample selection. Untuk itu Khandker, Koolwal dan Samad (2009) menyarankan untuk menggunakan status penerimaan Raskin pada periode lanjutan (2007) sebagai patokan. Dengan demikian dapat diasumsikan bahwa kelompok perlakuan adalah rumah tangga miskin yang menerima Raskin di 2007, sedangkan kelompok kontrol adalah rumah tangga miskin yang tidak menerima Raskin di 2007. Berdasarkan identifikasi tersebut jumlah rumah tangga sampel adalah sebanyak 1.106 rumah tangga yang terdiri atas 748 rumah tangga kelompok perlakuan dan 358 rumah tangga yang masuk dalam kelompok kontrol. Sampel inilah yang selanjutnya dilakukan proses pencocokan untuk membentuk kelompok kontrol yang karakteristiknya hampir sama dengan kelompok perlakuan. Hasil dari proses pencocokan dengan PSM, terdapat 1.097 rumah tangga yang berada di dalam area common support dan sisanya 9 rumah tangga berada di luar area common support sehingga tidak digunakan dalam penelitian (tabel 3).

Tabel 3. Kelompok perlakuan dan kontrol sebelum dan sesudah proses pencocokan

\begin{tabular}{lccc}
\hline & $\begin{array}{c}\text { Sebelum proses } \\
\text { pencocokan }\end{array}$ & \multicolumn{2}{c}{ Sesudah proses pencocokan } \\
Dalam area & $\begin{array}{c}\text { Luar area } \\
\text { common support }\end{array}$ & common support \\
\hline Kelompok perlakuan & 748 & 748 & 0 \\
Kelompok kontrol & 358 & 349 & -9 \\
Jumlah & $\mathbf{1 . 1 0 6}$ & $\mathbf{1 . 0 9 7}$ & $\mathbf{- 9}$ \\
\hline
\end{tabular}

Estimasi dampak program Raskin pada penawaran tenaga kerja dari 1.097 rumah tangga dilakukan dengan menggunakan metode Difference-in-Difference, yaitu dengan membandingkan outcome perubahan jam kerja pada kedua kelompok pada periode sebelum dan sesudah pelaksanaan Raskin. Dengan menggunakan persamaan (4), estimasi dampak Raskin pada penawaran tenaga kerja kepala rumah tangga, baik kepala rumah tangga berjenis kelamin laki-laki maupun perempuan. Hasil estimasi tersebut dapat dilihat pada tabel 4 . 
Tabel 4. Hasil estimasi dampak Raskin terhadap penawaran tenaga kerja

\begin{tabular}{ccc}
\hline \hline Sampel & Estimator DID $(\widehat{\boldsymbol{\delta}})$ \\
\hline Kepala rumah tangga & -2.857 & $* *$ \\
Laki-laki & -2.695 & $* *$ \\
Perempuan & -1.345 & \\
\hline
\end{tabular}

Hasil regresi di atas menujukkan bahwa pemberian Raskin memiliki dampak pada perubahan jam kerja dalam seminggu pada kepala ruamh tangga. Dengan tingkat signifikansi 5 persen dapat dilihat bahwa terjadi pengurangan jam kerja dalam seminggu sebesar 2,8 jam pada kepala keluarga dari rumah tangga penerima Raskin. Jika dilihat berdasarkan jenis kelaminnya, penurunan penawaran tenaga kerja akibat pemberian Raskin terjadi pada kepala rumah tangga berjenis kelamin laki-laki. Dengan tingkat signifikansi 5 persen, terjadi pengurangan jam kerja pada kepala rumah tangga laki-laki sebesar 2,7 jam. Sementara pada kepala rumah tangga perempuan tidak ditemukan pengurangan jam kerja yang signifikan. Hasil ini sama dengan hasil penelitian sebelumnya yang dilakukan oleh Rasyid (2012) dimana pemberian Raskin memiliki efek kontraproduktif berupa pengurangan penawaran tenaga kerja kepala rumah tangga. Namun untuk mengatakan bahwa efek kontraproduktif berupa pengurangan jam kerja tersebut menyebabkan kepala rumah tangga menjadi malas bekerja masih perlu dianalisis lebih lanjut

Dengan membandingkan rata-rata perubahan jam kerja kepala keluarga, dapat dilihat bahwa penurunan rata-rata jam kerja seluruh pekerjaan kepala rumah tangga laki-laki pada kelompok perlakuan sebesar 0,27 jam (tabel 5). Penurunan jam kerja ini cukup kecil sehingga tidak bisa dikatakan sebagai efek kontraproduktif. Lebih jauh penurunan jam kerja ini diduga merupakan penurunan jam kerja dari pekerjaan sampingan. Sedangkan kepala rumah tangga pada kelompok kontrol mengalami peningkatan rata-rata jam kerja sebesar 3,72 jam. Hal ini mengindikasikan bahwa kepala rumah tangga bukan penerima Raskin harus menambah waktu kerja dengan bekerja sampingan guna memenuhi kebutuhan rumah tangga mengingat terjadi inflasi yang tinggi pada akhir tahun 2005. Dengan demikian dapat dikatakan bahwa pemberian Raskin diduga meringankan beban pengeluaran rumah tangga sehingga kepala rumah tangga penerima Raskin tidak perlu bekerja ekstra seperti kepala rumah tangga bukan penerima Raskin.

Dalam kondisi seperti ini penurunan penawaran tenaga kerja kepala rumah tangga akibat pemberian Raskin bukan menyebabkan orang malas melainkan sebagai pengurangan jam kerja sampingan. 
Tabel 5. Rata-rata jam kerja kepala rumah tangga laki-laki

\begin{tabular}{lccr}
\hline \multicolumn{1}{c}{\begin{tabular}{c} 
Rata-rata jam kerja seminggu \\
\multicolumn{1}{c}{ kepala keluarga laki-laki }
\end{tabular}} & $\begin{array}{c}\text { Tahun } \\
\mathbf{2 0 0 5}\end{array}$ & $\begin{array}{c}\text { Tahun } \\
\mathbf{2 0 0 7}\end{array}$ & Perubahan \\
\hline Kelompok perlakuan & 37,061 & 36,788 & $-0,273$ \\
Kelompok kontrol & 34,154 & 37,880 & 3,726 \\
Perbedaan & 2,907 & $-1,092$ & $-3,999$ \\
\hline
\end{tabular}

\section{Kesimpulan}

Penelitian ini bertujuan untuk memeriksa kembali adanya efek kontraproduktif berupa pengurangan penawaran tenaga kerja dalam keluarga sebagai dampak dari pemberian subsidi Raskin. Hal ini dilakukan dengan melihat perbedaan perilaku kepala rumah tangga setelah menerima Raskin, yaitu dengan memeriksa apakah pemberian Raskin menyebabkan kepala rumah tangga menjadi malas dan mengurangi jam kerjanya.

Dari hasil estimasi ditunjukkan bahwa pemberian Raskin memiliki dampak signifikan pada penurunan rata-rata jam kerja kepala rumah tangga, khususnya pada kepala rumah tangga laki-laki. Walaupun hasil ini mengindikasikan adanya kontraproduktif Raskin pada penawaran tenaga kerja kepala rumah tangga, namun tidak berarti bahwa pemberian Raskin menyebabkan kepala rumah tangga menjadi malas bekerja. Dari perbandingan rata-rata jam kerja kelompok perlakuan dan kelompok kontrol diduga bahwa pemberian Raskin mengurangi beban pengeluaran kepala rumah tangga sehingga tidak perlu bekerja lebih banyak dibanding kepala rumah tangga bukan penerima Raskin.

Berdasarkan hasil tersebut dapat disimpulkan bahwa belum ditemukan adanya dampak negatif pemberian program Raskin pada penawaran tenaga kerja rumah tangga miskin pada periode penelitian 2005-2007. Namun demikian, hasil dari penelitian ini menunjukkan bahwa masih terjadi kesalahan penetapan sasaran penerima Raskin, baik itu exclusion maupun inclusion error. Oleh karena itu disarankan untuk memperbarui data sasaran rumah tangga miskin agar pemberian Raskin lebih tepat sasaran.

Dalam melakukan estimasi dampak Raskin terhadap penawaran tenaga kerja, penelitian ini memiliki beberapa keterbatasan, yaitu : (1) Keterbatasan data yang digunakan dalam metode DID. Penggunaan data Susenas tahun 2005 dan 2007, dimana merupakan periode setelah pelaksanaan Raskin, tidak sesuai dengan yang 
disyaratkan dalam teori sehingga berpotensi menghasilkan estimasi yang kurang baik. (2) Kelompok kontrol yang digunakan dalam penelitian ini memanfaatkan adanya exclusion error pada pelaksanaan Raskin. Jika program Raskin sudah didesain dengan baik dan tidak terjadi lagi kesalahan penetapan penerima Raskin maka penelitian ini tidak dapat lagi dilakukan.

\section{Daftar Pustaka}

Abdulai, A., Barret, C., Hoddinott. (2005). Does Food Aid Really Have Disincentive Effect? New Evidence from Sub-Saharan Africa. Word Development, Vol. 33, No. 10, pp. 1689-1704.

Badan Pusat Statistik (BPS). (2008). Analisis dan Perhitungan Kemiskinan 2008. Jakarta: Badan Pusat Statistik (BPS).

Barret, C. (2002). Food Aid Effectiveness: It's targeting, Stupid! New York : Working Paper Department of Applied Economics and Management WP 2002-43,.

Barrett, C. B. (2006). Food Aid's Intended and Unintended Consequences. FAO Working Paper 06-05.

Barrett,C. B. and Maxwell, Daniel G. (2005). Food Aid After Fifty. London: Routledge.

Bertrand, M., Duflo, E. \& Mullainatha, E. (2004). How Much Should We Trust Differences-In-Differences Estimates? The Quarterly Journal of Economics.

Browning, M., Bourguignon,F., Chiappori, PA., Lechene, V. (1994). Income and Outcomes: A Structural Model of Intrahousehold Allocation. Journal of Political Economy, Vol. 102 pp. 1067-1096.

Cahuc, P., Zylberberg, A. (2004). Labor Economics. The MIT Press.

Caliendo,M. dan Kopeinig, S. (2005). Some Practical Guidance for the Implementation of Propensity Score Matching. IZA Discussion Paper No. 1588.

Dhar, Tirtha., Chavas, Jean-Paul and Gould, Brian W.(2003). An Empirical Assessment of Endogeneity Issues in Demand Analysis for Differentiated. American Journal of Agricultural Economics,, Vol. 85, No. 3 (Aug., 2003), pp. 605-617.

Bappenas, Direktorat Kependudukan, Pemberdayaan Perempuan, dan Perlindungan Anak. (2010). Evaluasi Pelayanan KB Bagi Masyarakat Miskin (Keluarga Prasejahtera/KPS dan Keluarga Sejahtera-I/KS-I). Jakarta: Bappenas.

Flood, L., Hansen, J. \& Wahlber, R. (2004). Household Labor Supply and Welfare Participation in Sweden. The Journal of Human Resources, Vol. 39, No. 4, pp. 1008-1032.

Gertler,P., Martinez, S., Premand,P.,Rawlings, L., Vermeersch,C. (2011). Impact Evaluation in Practice. Washington DC: The World Bank.

Hagstrom, P. A. (1996). The Food Stamp Participation and Labor Supply of Married Couples: An Empirical Analysis of Joint Decisions. The Journal of Human Resources, Vol. 31, No. 2, pp. 383-403.

Hastuti, Mawardi,S., Sulaksono, B., Devina, S., Artha, R.P. (2008). Efektivitas Pelaksanaan 
Raskin. Jakarta: Lembaga Penelitian SMERU.

Jackson, T. and Eade, D. (1982) Against the Grain: The Dilemma of Project Food Aid.Oxfam.

Khandker,S.R.,Koolwal,G.B.,Samad.,H.A. (2009). Handbook on Impact Evaluation: Quantitative Methods and Practices. Washington DC: The World Bank.

Lechner, M. (2010). The Estimation of Causal Effects by Difference-in-Difference Methods. Econometrics Vol. 4, No. 3, 165-224.

Lee, M., Kang, C. (2006). Identification for difference in differences with cross-section and panel data. Economics Letters $92,270-276$.

Lentz, E., C. Barrett, and J. Hoddinott. (2005). Desk Review: Food Aid and Dependency: Implications for Emergency Food Security Assessments. Rome: World Food Programme.

Maxwell, S., D. Belshaw and A. Lirenso. (1994). The Disincentive Effect of Food-for-Work on Labour Supply and Agricultural Intensification in Ethiopia. Journal of Agricultural Economics, 45, 351-359.

Noyorono, O. (2012). Analisis Dampak Pelaksanaan Program Bantuan Langsung Tunai 2008/2009 Pada Konsumsi, Pendidikan, Kesehatan Dan Pola Bekerja Rumah Tangga (Disertasi). Depok: Program Pascasarjana Ilmu Ekonomi, FEB UI.

Rasyid, M. (2012). Efek Disinsentif Program RASKIN dan Pengaruhnya terhadap Transfer Pangan Antar Generasi. Jurnal Ekonomi Pembangunan, Volume 13, Nomor 1, Juni 2012, hlm.146-161 .

Sahn, David E., and Alderman, Harold . (1996). The Effect of Food Subsidies on Labor Supply in Sri Lanka. Economic Development and Cultural Change, Vol. 45, No. 1 pp. 125-145.

Sitepu, A. (2014). Faktor-Faktor Penyebab Ketidaktepatan Rumah Tangga Sasaran -Penerima Manfaat (RTS-PM) Program Subsidi Beras Bagi Masyarakat Berpenghasilan Rendah. Informasi, Vol. 19, No. 3.

Skoufias, E., Unar, M. \& Gonzalez-Cosio. (2008). The Impacts of Cash and In-Kind Transfers on Consumption and Labor Supply : Experimental Evidence from Rural Mexico. World Bank Policy Research Working Paper 4778.

Stevens, C.(1979).Food Aid and the Developing World: Four African Case Studies. Croom Helm, London.

Stiglitz, J. (2000). Economics of Public Sector 3rd Edition. New York: W. W. Norton \& Company.

Sulaiman, M. (2010). Incentive and crowding out effects of food assistance: Evidence from randomized evaluation of food-for-training project in Southern Sudan. London: London School of Economics and Political Science.

White, H. dan Sabarwal, S. (2014). Quasi-Experimental Design and Methods. Methodological Briefs Impact Evaluation No. 8. 